\title{
PELEMBAGAAN KARAKTER TOLERANSI SISWA MELALUI PROGRAM PENDIDIKAN BERKARAKTER PURWAKARTA
}

\author{
Thaufan $^{1}$, Sapriya ${ }^{2}$ \\ ${ }^{1}$ Mahasiswa Departemen Pendidikan Kewarganegaraan SPS UPI, ${ }^{2}$ Dosen Departemen \\ Pendidikan Kewarganegaraan SPS UPI \\ Email : thaufan.abiyuna@yahoo.co.id ${ }^{1}$
}

Naskah diterima: 16/11/2017 revisi: 26/03/2018 disetujui: 23/04/2018

\begin{abstract}
Abstrak
Pemerintah Purwakarta mengeluarkan program Pendidikan Berkarakter yang ditandai dengan Peraturan Bupati Nomor 69 Tahun 2015 sebagai upaya pelembagaan toleransi siswa. Tujuan penelitian ini untuk mengetahui implementasi Pendidikan Berkarakter dalam menumbuhkan karakter toleransi antar umat beragama siswa di SMP Negeri 1 Purwakarta. Dengan menggunakan pendekatan kualitatif dan metode studi kasus, penelitian dilakukan melalui metode pengumpulan data wawancara, observasi, dan studi dokumentasi. Hasilnya adalah bahwa Pendidikan Berkarakter diimplementasikan dalam tiga basis yaitu dalam pembelajaran di kelas, dalam ekstrakurikuler, dan dalam pembiasaan sekolah. Beberapa contoh kegiatannya yaitu tujuh Poe atikan Purwakarta Istimewa, pendalaman kitab kuning, penyedia 5 ruang ibadah dan lain-lain.
\end{abstract}

Kata kunci: Pelembagaan toleransi, implementasi pendidikan berkarakter.

\section{INSTITUTIONALIZATION OF STUDENT TOLERANCE CHARACTER THROUGH CHARACTER EDUCATION PROGRAM PURWAKARTA}

\begin{abstract}
Purwakarta Government issued a Character Education program which is marked by Regent Regulation No. 69 of 2015 as an effort to institutionalize student tolerance. The purpose of this study is to know the implementation of Character Education in fostering the character of tolerance among religious people in SMP Negeri 1 Purwakarta. By using qualitative approach and case study method, research is done through interview data collection method, observation, and documentation study. The result is that Character Education is implemented in three bases namely in classroom learning, in extracurricular, and in school habituation. Some examples of activities are seven Poe Suppose Purwakarta Istimewa, deepening yellow book, providers of 5 prayer space and others.
\end{abstract}

Keywords: Institutionalization of tolerance, implementation of character education. 


\section{PENDAHULUAN}

Keberagaman merupakan kekayaan terbesar bagi bangsa ini, jika didukung oleh jiwa toleransi warganya dalam kehidupan membangsa dan menegara. Namun dewasa ini, keberagaman yang toleran justru terancam oleh adanya berbagai gesekan yang dapat menerbitkan air mata keresahan dari seluruh warga di pelosok tanah air yang ramai dari pemberitaan di media massa. Beragam konflik ini lahir karena beberapa hal pokok yang mendasarinya. Pertama, ideologi radikalisme yang sudah tertanam dalam pikiran warga menjadi modal untuk melawan ideologi Pancasila, sehingga kerap melahirkan peperangan antar kedua ideologi ini. Selanjutnya terdapat berbagai ancaman disintegrasi yang diakibatkan dari intoleransi warga negara yang mudah terpengaruh oleh berita-berita bohong. Masyarakat yang majemuk dan multikultural menjadikan persamaan pandangan adalah kenicayaan yang sulit diwujudkan. Maka perbedaan pandangan akibat dari keberagaman itulah yang justru menjadi bagian dari pertentangan yang ada dalam masyarakat Indonesia. Intoleransi dalam keberagaman tersebut merupakan salah satu indikasi keterpurukan moral bangsa yang harus mendapat perhatian lebih untuk segera diselesaikan.

Berbagai permasalahan tersebut dapat ditanggulangi dengan penyelenggaraan pendidikan formal yang baik. Penyelenggaraan pendidikan formal tersebut harus bermuara pada pendidikan nasional. UU RI No. 20 tahun 2003 tentang Sistem Pendidikan Nasional pada pasal 2 menyatakan bahwa Pendidikan nasional adalah pendidikan yang berdasarkan Pancasila dan UUD Negara RI Tahun 1945, yang berakar pada nilai-nilai agama, kebudayaan nasional Indonesia, dan tanggap terhadap tuntutan perubahan zaman. Dengan semangat penyelenggaraan pendidikan nasional yang diupayakan bersama, permasalahan moral, disintegrasi, dan intoleransi dapat diselesaikan.

Penyelenggaraan pendidikan nasional melalui pendidikan formal sekolah harus dilakukan dengan mendesain pendidikan karakter. Elkind dan Freddy (dalam Zubaedi, 2011, hlm. 15) 'character education is the deliberate effort to help people understand, care about, and act upon core ethical value. Purwasasmita (2010, hlm. 14) pembangunan karakter merupakan proses mengukir atau memahat jiwa sedimikian rupa, sehingga berbentuk unik, menarik, dan berbeda atau dapat dibedakan dengan orang lain. Dua pendapat tersebut menunjukkan bahwa pendidikan karakter merupakan upaya sadar dan sistematis untuk membentuk individu yang memiliki cara berpikir, bersikap, dan bertindak yang unik dan berbeda dari yang lain namun tetap menunjukkan pada nilai-nilai yang berlaku dalam lingkungannya.

Pendidikan Berkarakter merupakan salah satu program yang diberlakukan oleh pemerintah Purwakarta dengan tujuan untuk beberapa hal berikut yaitu: (1) sebagai pedoman bagi guru dalam memberikan bimbingan dan pengasuhan yang merupakan bagian tidak terpisahkan dari proses pembelajaran terhadap Peserta Didik di sekolah; (2) melatih Peserta Didik untuk membiasakan pola hidup tertib, mandiri, peduli, dan peka terhadap lingkungan sekitarnya dengan mengaplikasikan nilai-nilai yang diperkenalkan melalui proses pembelajaran di sekolah; (3) menjadikan satuan pendidikan sebagai sarana pembentukan sikap dan perilaku positif dari Peserta Didik yang tidak terpisahkan dengan rumah dan lingkungan tempat tinggalnya; (4) menjalin hubungan yang harmois dan sinergis antara guru dan orang tua Peserta Didik dalam mewujudkan cita-cita pendidikan dalam arti yang seluas-luasnya; dan (5) memberikan pedoman bagi Pemerintah Daerah dalam merencanakan dan merumuskan kebijakan di bidang pendidikan yang langsung menyentuh pada aspek pembinaan mental dan spiritual Peserta Didik yang terintegrasi dengan aspek yang bersifat kurikuler.

Pendidikan Berkarakter menjadi upaya operasional dari pemerintah Purwakarta untuk memperjelas mekanisme operasional pendidikan karakter yang disesuaikan dengan lingkungan budaya Purwakarta sebagai daerah berbudaya. Pendidikan berkarakter adalah suatu usaha satuan pendidikan untuk membina meningkatkan kualitas siswa yang berhubungan pembiasaan atau karakter atau prilaku yang digunakan. Pendidikan berkarakter merupakan kesadaran untuk melakukan upaya-upaya dalam membina dan peningkatkan kualitas diri siswa melalui penanaman karakter dan pembiasaan pada satuan pendidikan.

$\begin{array}{clrr}\text { Salah } & \text { satu pemberlakuan } & \text { program } \\ \text { Pendidikan } & \text { Berkarakter adalah } & \text { untuk }\end{array}$ 
melembagakan karakter toleransi siswa. Poerwadarminta (1982, hlm. 1084) menyatakan toleransi adalah sikap/sifat tenggang rasa berupa menghargai serta membolehkan suatu pendirian, pendapat, pandangan, kepercayaan maupun yang lainnya yang berbeda pendirian sendiri. Pendapat tersebut menjelaskan bahwa toleransi merupakan sikap tenggang rasa, dan pemberian kebebasan bagi orang lain untuk bersikap, berkeyakinan dan melakukan hal-hal yang berbeda dari dirinya.

SMP Negeri 1 Purwakarta merupakan institusi pendidikan formal yang mengimplementasikan program pendidikan berkarakter untuk melatih siswa agar mampu melembagakan karakter toleransi dalam kehidupan sehari-hari. SMP Negeri 1 Purwakarta berupaya melatih siswa untuk terbiasa menghadapi perbedaan dan menciptakan lingkungan yang kondusif dalam melatih siswa bertoleransi. Adapun penelitian ini bertujuan untuk mengetahui bagaimana implementasi Pendidikan Berkarakter di SMP Negeri 1 Purwakarta.

\section{METODE}

Berisi jenis penelitian, waktu dan tempat penelitian, target/sasaran, subjek penelitian, prosedur, instrumen dan teknik analisis data serta hal-hal lain yang berkait dengan cara penelitiannya. target/sasaran, subjek penelitian, prosedur, data dan instrumen, dan teknik pengumpulan data, serta teknik analisis data serta hal-hal lain yang berkait dengan cara penelitiannya dapat ditulis dalam sub-subbab, dengan sub-subheading. Sub-subjudul tidak perlu diberi notasi, namun ditulis dengan huruf kecil berawalkan huruf kapital, TNR-12 unbold, rata kiri. Sebagai contoh dapat dilihat berikut.

\section{Jenis Penelitian}

Penelitian ini menggunakan pendekatan kualitatif. Menurut Creswell (1998, hlm. 15), penelitian kualitatif adalah proses penelitian untuk memahami berdasarkan tradisi metodologi penelitian tertentu dengan cara menyelidiki masalah sosial atau manusia.Peneliti membuat gambaran kompleks yang bersifat holistik, menganalisis kata-kata, melaporkan pandangan-pandangan para informan secara rinci, dan melakukan penelitian dalam situasi alamiah. Dengan penelitian kualitatif memungkinkan peneliti untuk meneliti obyek secara alamiah tanpa ada pengondisian apapun, sehingga hasil yang didapat akan sesuai dengan bagaimana fenomena-fenomena yang diteliti dan bergantung kepada peneliti. Metode yang digunakan yaitu studi kasus. Dengan metode ini memungkinkan peneliti dapat lebih leluasa memahami fenomena-fenomena yang terjadi di lapangan untuk dianalisis lebih mendalam.

\section{Waktu dan Tempat Penelitian}

Lokasi penelitian bertempat di SMP Negeri 1 Purwakarta yang tepatnya berada di Jalan Kol. Kornel Singawinata No. 60 Kabupaten Purwakarta Provinsi Jawa Barat. Sekolah ini dipilih sebagai lokasi penelitian karena telah menerapkan Program Pendidikan Berkarakter sesuai dengan Perbup Nomor 69 Tahun 2015 tentang pendidikan Berkarakter. Selain itu sekolah ini ditunjuk oleh pemerintah Kabupaten Purwakarta sebagai sekolah percontohan dalam mengembangkan sikap toleransi antar umat beragama.

\section{Target/Subjek Penelitian}

Adapun yang menjadi subjek dalam penelitian ini adalah sebagai berikut: (1) Kepala Dinas Pendidikan Kabupaten Purwakarta yaitu PW. (2) Guru Pendidikan Pancasila dan Kewarganegaraan (PPKn) di SMPN 1 Purwakarta yaitu PT. (3) Kepala SMP Negeri 1 Purwakarta yaitu HW. (4) Siswi SMP Negeri 1 Purwakarta yang beragama Hindu yaitu AY. (5) siswi SMP Negeri 1 Purwakarta yang beragama Katolik yaitu YR. (6) Wakil Kepala Sekolah Bidang Kesiswaan yaitu DR. Subjek penelitian dipilih menggunakan teknik Proportional random sampling.

\section{Prosedur}

Prosedur penelitian ini dilakukan melalui observasi terlebih dahulu kemudian dilanjutkan denganpenyusunan proposal. Setlah proposal selesai langkah selanjutnya yakni pengumpulan datan dan analisis data. Pada bagian terakir dilakukan pengambilan kesimpulan

\section{Data, Intrumen, dan Teknik Pengumpulan Data}

Dalam penelitian ini, peneliti menggunakan empat teknik pengumpulan data, yaitu dengan wawancara, observasi, dan studi dokumentasi.

\section{Teknik Analisis Data}

Adapun teknik analisis data yang digunakan yaitu dengan reduksi, display, dan 
verifikasi atau pengambilan kesimpulan. Proses analisis data dilakukan sejak sebelum terjun ke lapangan, selama di lapangan dan setelah selesai di lapangan. Setelah analisis, peneliti melakukan validasi data dengan empat teknik yaitu meningkatkan ketekunan, triangulasi data, menggunakan referensi yang cukup dan melakukan member check.

\section{HASIL DAN PEMBAHASAN}

\section{Hasil}

Purwakarta merupakan salah satu Kabupaten yang menerapkan kebijakan pendidikan yang unik dan berbasis pada kearifan lokal. Penyelenggaraan pendidikan di Purwakarta dilakukan dengan menerapkan pendidikan berkarakter, yaitu pendidikan yang khas dan unik sebagai produk hukum dari para pemangku kebijakan pemerintah Kabupaten. Dalam pendidikan berkarakter ini, ada program yang dinamakan dengan Tujuh Poe Pendidikan Istimewa.

Berdasarkan hasil lapangan, HW pendidikan berkarakter adalah suatu usaha satuan pendidikan untuk membina meningkatkan kualitas siswa yang berhubungan pembiasaan atau karakter atau prilaku yang digunakan. Pendidikan berkarakter merupakan kesadaran untuk melakukan upaya-upaya dalam membina dan peningkatkan kualitas diri siswa melalui penanaman karakter dan pembiasaan pada satuan pendidikan. Selain itu, PT menjelaskan bahwa pendidikan berkarakter adalah bagaimana nilai-nilai karakter di laksanakan dalam kehidupan sehari hari.

Pendidikan berkarakter dari sudut pandang AY sebagai siswa, merupakan bentuk pembiasaan yang diterapkan di sekolah. Pendidikan berkarakter adalah ciri khas pendidikan di Purwakarta yang menuntut seluruh siswa agar mampu berperilaku sesuai dengan kekhasan daerah Purwakarta.

Adapun tujuan dari implementasi Pendidikan Berkarakter di sekolah yang pertama adalah untuk menanamkan sekaligus menjadikan pendidikan karakter bukan pada tataran teoritis, melainkan sudah berada pada tataran praktis. Ini merupakan upaya untuk melahirkan generasi yang tangguh.

Kedua memberikan pedoman operasional penerapan pendidikan karakter di sekolah untuk menjawab tantangan jaman. Ketiga menciptakan peserta didik yang memiliki toleransi yang tinggi, memiliki kecintaan terhadap culture identity dan menyiapkan mereka menjadi warga negara yang berintegritas dan berciri khas.

Keempat memberikan pembiasaan kepada pihak sekolah dan masyarakat agar ikut serta menyelenggarakan pendidikan yang bersinergi. Sedangkan yang kelima yakni menguatkan karakter-karakter religius peserta didik.

Berkaitan dengan jenis kegiatan yang dilaksanakan, berdasarkan hasil lapangan diketahui bahwa program-program yang direalisasikan Pemerintah Purwakarta adalah sebagai berikut:

\section{Tujuh Poe Atikan Purwakarta Istimewa}

Program ini adalah program yang mengharuskan setiap sekolah untuk menerapkan karakter-karakter yang berbeda di setiap harinya. hari senin untuk program di atas dinamakan Ajeg Nusantara. Hari selasa, Mapag di Buana atau menjemput dunia. Maksudnya anak-anak akan diberikan pengetahuan tentang dunia internasional. Hari rabu Maneuh di Sunda, muatannya berisi pendidikan khas Sunda. Kamis diberi nama Nyanding Wawangian, ini hari khusus belajar estetika. Di hari kamis murid belajar sastra, mendekorasi ruangan dan lain sebagainya. Hari Jumat diberi nama Nyucikeun Diri yang berisi penanaman nilai spiritual dan kebersihan lingkungan. Untuk hari Sabtu dan Minggu diberi nama Betah di Imah karena hari libur anak sekolah.

\section{Pembiasaan sekolah}

Pembiasaan sekolah berupa makan bekel, ucap salam, dan WC bersih merupakan bentuk dari realisasi program Pendidikan Berkarakter Purwakarta yang bertujuan memberikan pembiasaan yang membuat siswa tidak sembarang makan makanan yang tidak sehat, membiasakan untuk selalu santun dan mengucap salam dimanapun ia berada, dan membiasakan untuk selalu hidup bersih.

\section{Pendidikan vokasional}

Pendidikan vokasional, yaitu program pendidikan Berkarakter Purwakarta dimana di beberapa sekolah, hari selasa diliburkan agar anak-anak dapat membantu orang tuanya untuk bekerja baik di ladang maupun di tempat bekerja lainnya. Umumnya program ini dilaksanakan pada hari sabtu atau minggu dan diserahkan kepada orang tua siswa masing-masing.

\section{Pendalaman Kitab Kuning}

Pendalaman Kitab Kuning di Sekolah, yaitu program yang bertujuan dalam rangka memperkaya khazanah pemikiran keislaman pelajar Purwakarta, program pendalam kitab kuning, juga bertujuan untuk mensejajarkan 
antara lulusan pesantren dengan lulusan pendidikan umum. Tujuan ini dilatarbelakangi dengan masih terdapat stigma di tengah masyarakat, bahwa lulusan pesantren tidak bisa ikut andil untuk memajukan masyarakat sekitar.

\section{Botram Harmoni}

Botram Harmoni, yaitu program yang dilakukan oleh Pemerintah Kabupaten Purwakarta yang berisi makan bersama saling suap menyuap makanan antara siswa-siswa yang berbeda agama di Pendopo Purwakarta. Kegiatan ini bertujuan untuk menjalin kebersamaan dalam perbedaan khususnya perbedaan agama. Siswa dilatih untuk saling menghargai dan dibiasakan untuk berteman dengan siswa lain yang beragama berbeda.

\section{Penyediaan Lima Ruang Ibadah}

Program ini direalisasikan untuk memberikan sarana peribadatan kepada sekolah agar setiap anak dapat melaksanakan peribadatan sesuai dengan agama yang dianutnya masing-masing. Dalam program ini siswa diajarkan untuk saling menghormati tata cara peribadatan dan saling menghargai ketika ada temannya yang akan beribadah ditempat yang telah disediakan.

Dari beberapa kegiatan di atas, Progamprogram yang dilaksanakan di SMP Negeri 1 Purwakarta diantaranya adalah Pendalaman Kitab Kuning, Penyediaan sarana peribadatan setiap agama yang dianut siswa, Pendidikan Berkurban, Permainan Tradisional, Tujuh Poe Atikan Purwakarta, Makan Bekel, pembiasaan ikrar ber-Pancasila dan pendidikan vokasional.

Implementasi Pendidikan Berkarakter memiliki mekanisme sistematis yang dilaksanakan sekolah. Adapun mekanismenya diawali dengan tahap persiapan, tahap pelaksanaan, dan tahap evaluasi. Adapun tahap persiapan berdasarkan keterangan HW, dilaksanakan ketika perencanaan program sekolah di awal tahun pelajaran. Seluruh civitas sekolah khususnya guru melakukan perencanaan program sekolah. Program-program tersebut kemudian dirinci dan dipersiapkan seluruh penanggung jawabnya dan dimasukkan ke dalam kalender khusus pendidikan di SMP Negeri 1 Purwakarta. Dari perencanaan itu sudah ditentukan rencana kegiatan secara garis besarnya, waktu dan tempatnya, serta kepanitiannya. Tidak terkecuali program Pendidikan Berkarakter, setelah sekolah mendapatkan intruksi dari dinas pendidikan, penerapannya diawali dengan mengadakan perencanaan di awal tahun dan kemudian dirinci apa saja yang harus dilaksanakan serta bagaimana pelaksanaannya dibicarakan dalam rapat awal tahun pelajaran tersebut.

Program Pendidikan Berkarakter di SMP Negeri 1 Purwakarta di implementasikan ke dalam beberapa aspek, diantaranya adalah dalam pembelajaran di kelas atau program kurikuler, dalam ekstrakurikuler, dan dalam pembiasaan di sekolah maupun di luar sekolah. Adapun beberapa deskripsi berdasarkan hasil temuan lapangan disajikan dalam uraian berikut:

\section{Implementasi dalam Pembelajaran di Kelas}

Pembelajaran di kelas adalah rutinitas penting yang menjadi ruh pelaksanaan kurikulum dan sekaligus menjadi wadah interaksi antara pendidik dan peserta didik secara langsung. Dalam pembelajaran di Kelas, implementasi pendidikan berkarakter dilihat dari berbagai kegiatan yang dilaksanakan di dalam pembelajaran setiap mata pelajaran.

Adapun beberapa proses pelaksanaannya meliputi: (1) pelaksanaan berliterasi untuk membuka wawasan dengan membaca buku sebelum pembelajaran dimulai; (2) mengucap ikrar berpancasila sebelum pembelajaran dimulai; (3) Mendengarkan atau menyanyikan langsung lagu-lagu sesuai dengan tema hari yang ditentukan dalam program Tujuh Poe Atikan Purwakarta, misalnya lagu nasional dan lagu daerah; (4) memberikan pembelajaran dengan menerapkan Penguatan Pendidikan Karakter dalam setiap mata pelajaran, khusus PPKn dan PAI diberikan porsi yang lebih dalam melaksanakan pembinaan karakter di kelas; (5) melakukan pengelolaan kelas yang menguatkan kolaboratif siswa; dan (6) melakukan pembelajaran dengan pendekatan kontekstual serta menggunakan metode-metode yang menguatkan pengetahuan, sikap, maupun keterampilan siswa di setiap mata pelajarannya.

\section{Implementasi dalam Ekstrakurikuler}

SMP Negeri 1 Purwakarta memili berbagai ekstrakurikuler baik meliputi bidang olah raga, seni, kerohanian, maupun pengembangan diri bidang lainnya. Beberapa ekstrakurikuler tersebut diantaranya yaitu Pramuka, Paskibra, Palang Merah Remaja (PMR), Patroli Keamanan Sekolah (PKS), Pecinta Alam (PA), Olahraga (Perisai Diri, Volley Ball, Basket, Karate, Tenis Meja, Tenis Lapangan, Bulutangkis), Kerohanian/Ikatan 
Remaja Masjid (Ikatan Remaja Masjid AtTarbiyah), Koperasi Sekolah (Kopsis), English Corner (Bahasa Inggris), Science Club (IPA), Math Club (Matematika), Angklung, Seni Tari, dan Paduan Suara. Setiap ekstrakurikuler tersebut sangat memperkuat nilai-nilai karakter khususnya religius, jujur, toleransi, disiplin, kerja keras, dan mandiri.

Dalam pelaksanaannya, khususnya untuk menerapkan nilai-nilai religius, setiap waktu Ashar, aktivitas ekstrakurikuler dihentikan untuk menunaikan shalat berjamaah dengan imamnya bergiliran dari setiap ekstrakurikuler yang sedang berkegiatan. Implementasi Pendidikan Berkarakter juga dicerminkan dalam pelaksanaan kegiatan pendalaman kitab kuning yang dilaksanakan untuk memberikan pengetahuan tentang berbagai kitab kuning yang dipelajari di pesantren-pesantren.

\section{Implementasi dalam Pembiasaan Sekolah dan Luar Sekolah}

Dalam pembiasaan sekolah, Pendidikan Berkarakter diimplementasikan dalam pelaksanaan program Tujuh Poe Atikan Purwakarta Istimewa dengan rincian Senin yaitu Ajeg Nusantara yang artinya dengan berpakaian pramuka, hari senin dikhususkan berbicara tentang bagaimana keunggulan Indonesia dan seluruh aspek yang ada di dalamnya dan dikaitkan dengan pembelajaran masing-masing mata pelajaran.

Selasa yaitu Mapag Buana yaitu pembiasaan dimana siswa diarahkan untuk mengenal berbagai khazanah ilmu dunia. Siswa diajak untuk berbahasa Inggris dalam aktivitasnya dan tujuan pembiasaan Mapag Buana ini adalah agar siswa tetap berpikir global dan menyiapkan siswa untuk menjadi bagian dari masyarakat internasional. Rabu yaitu Maneuh di Sunda, artinya di hari rabu siswa dibiasakan untuk memakai pakaian sunda dan menerapkan nilai-nilai kesundaan. Guru harus menjelaskan berbagai tradisi, permainan dan nilai-nilai masyarakat sunda agar siswa mampu membangkitkan dan menegakkan nilai hidup kesundaan.

Kamis yaitu Nyanding Wawangi atau hari estetis yaitu siswa didorong untuk kreatif dan inovatif mengembangkan potensinya untuk mencipta hal-hal yang bersifat estetis, baik dalam bentuk sastra ataupun dengan bentuk lain yang disesuaikan dengan mata pelajarannya.
Jumat yaitu Nyucikeun Diri merupakan tema yang berarti menyucikan diri. Dengan tema hari jumat ini, siswa didorong untuk bertafakur dan mendekatkan diri kepada Tuhan dengan memperkuat ritualitas dan spiritualitas masingmasing diri siswa sesuai agama dan kepercayaannya. Hari Jumat, setiap paginya siswa diharuskan untuk mengikuti kegiatan keagamaan ditempat-tempat yang telah disediakan. Siswa yang beragama islam melaksanakan pembiasaan di Lapang, dan agama lainnya di tempat-tempat peribadatan yang telah sekolah sediakan. Dengan ini mereka diajak untuk bersama mendekatkan diri kepada Tuhan. Sabtu dan minggu yaitu Betah di Imah menjadi hari untuk siswa beraktivitas bersama orang tuanya masing-masing. Dalam momentum ini, siswa juga bisa belajar vokasional dengan membantu orang tuanya bekerja atau mengajak ke tempat-tempat produksi barang tertentu.

Selain penerapan pembiasaan itu, beberapa pembiasaan sekolah yang menjadi bentuk implementasi dari Pendidikan Berkarakter yaitu makan bekel yang artinya siswa selalu dibiasakan untuk membawa bekal makanan dari rumah dan dimakan secara bersama ketika istirahat di sekolah. Seringkali SMP Negeri 1 Purwakarta mengikuti kegiatan toleransi yang dilaksanakan oleh pemerintah Kabupaten setiap satu bulan sekali. Dalam kegiatan itu, siswa diajak untuk makan bersama saling suap menyuap makanan antara siswa yang berbeda agama. Pembiasaan yang dilakukan setiap tahun yaitu program berkurban. Program ini mengajak siswa SMP Negeri 1 Purwakarta untuk berkurban dan mengurus pembagian kurbannya keseluruhan.

PT menjelaskan bahwa monitoring evaluasi dilaksanakan secara insidental. Artinya Dinas setiap beberapa bulan sekali melakukan kunjungan ke sekolah untuk mengontrol dan mengevaluasi pelaksanaan program Pendidikan Berkarakter di SMP Negeri 1 Purwakarta. Hal tersebut dibenarkan oleh PW yang menyatakan bahwa pengawas termasuk pihak dinas mengontrol secara langsung dengan berkeliling ke sekolah. Pemerintah Kabupaten mengecek jalannya program apakah sesuai dengan Standar operasionalnya atau tidak. Selain itu, dalam mengadakan evaluasi, dinas mengumpulkan kepala sekolah untuk mengumpulkan laporan tentang implementasi dan mendiskusikan masalah-masalah yang terjadi dalam implementasi Program Pendidikan Berkarakter. 
HW menjelaskan monitoring dari sudut pandang sekolah sebagai pihak evaluator dan yang memonitor kegiatan siswa. Dalam pelaksanaan evaluasi karakter, siswa diberikan buku kendali dalam satu semester sekali untuk mencatat perilakunya sehari-hari. Dari mulai bangun, shalat, berangkat ke sekolah, shalat duha, shalat berjamaah, belajar sampai siswa tidur kembali. Catatan tersebut sebagai motivasi bagi siswa untuk terus membangun karakter dalam kesehariannya. Adapun kegiatan-kegiatan yang terlaksana disekolah, dicatat dan dimonitor oleh guru yang membimbing kegiatan tersebut. Monitoring juga dilakukan dengan home visit oleh guru-guru untuk melihat aktivitas siswa ketika di rumah sebagai bahan evaluasi untuk kegiatan vokasional. Hasil monitoring ini kemudian dimasukan ke dalam penilaian sikap siswa.

\section{Pembahasan}

Pendidikan yang baik adalah pendidikan yang mengupayakan adanya pembangunan karakter (character building) yang menurut Purwasasmita (2010, hlm. 14) pembangunan karakter merupakan proses mengukir atau memahat jiwa sedimikian rupa, sehingga berbentuk unik, menarik, dan berbeda atau dapat dibedakan dengan orang lain. Proses pembangunan karakter dalam pendidikan harus dilaksanakan secara bertahap dan berkesinambungan. Diawali dengan penanaman atau pembentukan, kemudian dilanjutkan dengan pengembangan pada usia remaja. Pada usia dewasa dilakukan pemantapan karakter yang pada akhirnya di usia tua dilaksanakan pembijaksanaan.

Pendidikan karakter dengan pendidikan berkarakter seperti dua istilah yang sama. Namun setelah dibandingkan, dua konsep ini berbeda namun memiliki beberapa persamaan. Pendidikan karakter menurut Creasy (dalam Zubaedi, 2011, hlm. 16) adalah upaya mendorong peserta didik tumbuh dan berkembang dengan kompetensi berpikir dan berpegang teguh pada prinsip-prinsip moral dalam hidupnya serta mempunyai keberanian melakukan yang benar meskipun di hadapkan pada berbagai tantangan. Dalam hal ini pendidikan karakter lebih kepada pengenalan nilai moral agar menjadi pegangan dalam melakukan sesuatu untuk menjadikan individu sebagai manusia yang berani dalam menghadapi segala tantangan. Sedangkan pendidikan berkarakter menurut hasil lapangan diartikan sebagai suatu usaha satuan pendidikan untuk membina meningkatkan kualitas siswa yang berhubungan pembiasaan atau karakter atau prilaku yang digunakan. Pendidikan Berkarakter merupakan kesadaran untuk melakukan upayaupaya dalam membina dan peningkatkan kualitas diri siswa melalui penanaman karakter dan pembiasaan pada satuan pendidikan.

Program Pendidikan Berkarakter dilaksanakan sebagai strategi pengembangan karakter secara makro yang dibuat oleh Pemerintah Kabupaten Purwakarta yang selanjutnya diterjemahkan ke dalam strategi pengembangan karakter mikro dalam konteks SMP Negeri 1 Purwakarta sebagai satuan pendidikan. Zubaedi (2011, hlm. 198) menyatakan bahwa strategi pengembangan karakter secara makro artinya keseluruhan konteks perencanaan dan implementasi pengembangan nilai atau karakter melibatkan pemangku kepentingan pendidikan nasional. Dalam hal ini, Pemerintah Purwakarta menjadi pelaku pengembangan karakter secara makro karena melibatkan berbagai pemangku kepentingan dalam lingkup wilayah Kabupaten. Sedangkan SMP Negeri 1 Purwakarta menjadi pihak pengembang karakter secara mikro dalam lingkup sekolah.

Berdasarkan hasil data lapangan, penyelenggaraan pengembangan nilai-nilai karakter dilakukan pemerintah Kabupaten Purwakarta berpijak pada tiga hal, yaitu pandangan filosofis, teoritis, dan empiris. Pandangan filosofis mempertimbangkan pengembangan sesuai dengan agama, Pancasila, Undang-Undang Dasar Negera Republik Indonesia Tahun 1945, dan Undang-Undang Nomor 20 Tahun 2003. Pandangan teoritis mempertimbangkan pengembangan pada teoriteori psikologis, nilai moral, dan pedagogis. Selanjutnya pandangan empiris, pengembangan karakter yang dilakukan Kabupaten Purwakarta dengan mempertimbangkan pengalaman dan praktik terbaik dari berbagai pihak.

Implementasi pendidikan karakter secara sistem menjadi gambaran kerjasama yang serius antara pembuat kebijakan dan seluruh pelaksana kebijakan untuk mencapai tujuan. Inti dari implementasi dari Pendidikan berkarakter yang dimulai pada tahun 2015 ini ditinjau penerapannya pada proses yang meliputi proses perencanaan, pelaksanaan dan evaluasi. Penerapan di SMP Negeri 1 Purwakarta meliputi 
berbagai proses yang digambarkan dalam pada

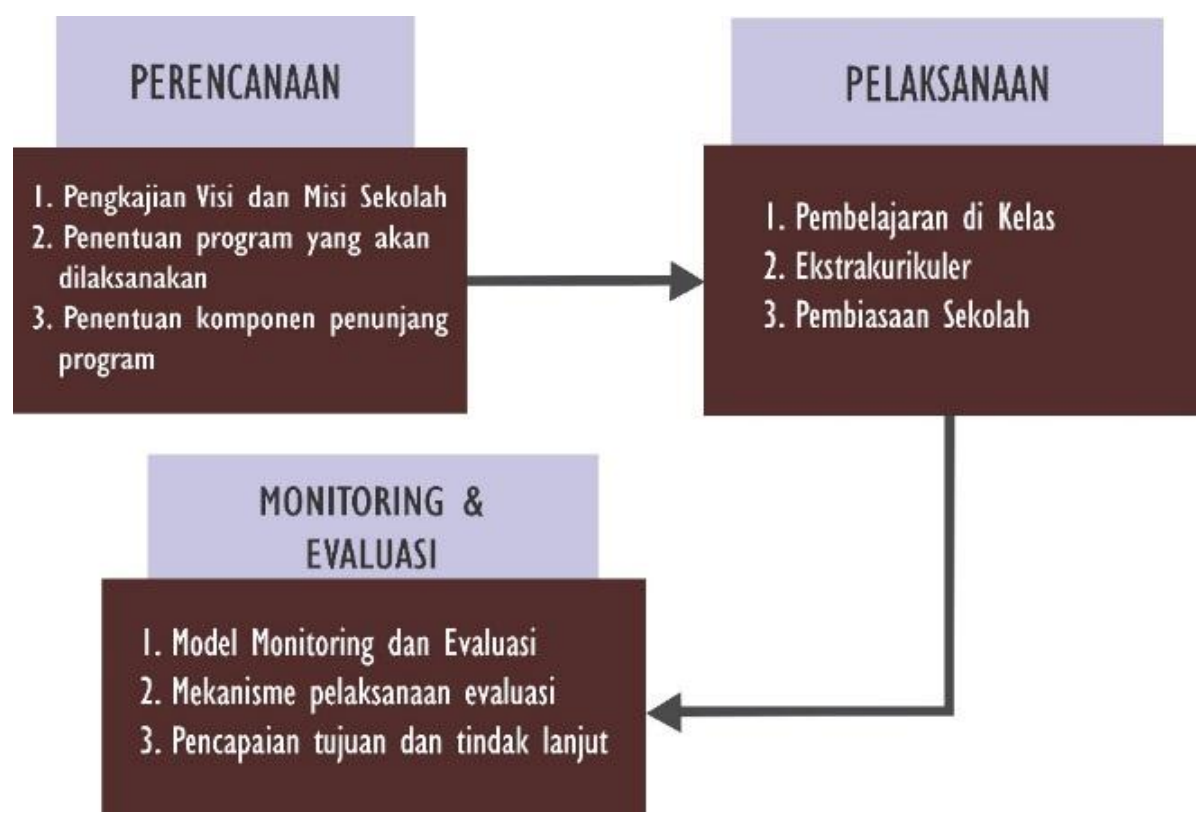

gambar 1 berikut.

Gambar 1 Pelaksanaan Pendidikan Karakter di SMPN 1 Purwakarta

Dari skema di atas, diketahui bahwa sekolah merupakan satuan pendidikan yang berperan sebagai leading sector yang menjadikan Program Pendidikan Berkarakter sebagai kebijakan untuk menginisasi, memperbaiki, menguatkan, dan terus menyempurnakan proses pendidikan karakter bagi peserta didik. Berikut penjelasan tahaptahap implementasi Pendidikan Berkarakter di SMP Negeri 1 Purwakarta

\section{Perencanaan}

Perencanaan merupakan tahap awal yang menentukan keberhasilan suatu program. Nicholas White, direktur Crisis Group International yang merupakan NGO yang berpusat di Belgia (dalam Suharto, 2014, hlm. 71) menyatakan bahwa "if we fail to plan, we plan to fail" yang berarti jika kita gagal dalam perencanaan. Maka, para pemangku kebijakan di SMP Negeri 1 Purwakarta menganggap bahwa perencanaan adalah tahap yang harus didiskusikan secara serius agar langkah ke depan sesuai dengan harapan.

Suharto (2014, hlm. 71-72) menyatakan bahwa pada hakikatnya perencanaan merupakan usaha secara sadar, terorganisir dan terus menerus dilakukan guna memilih alternatif yang terbaik dari sejumlah alternatif yang ada untuk mencapai tujuan tertentu. Perencanaan dilaksanakan pihak SMP Negeri 1 Purwakarta untuk memberikan penguatan terhadap kebijakan yang dikeluarkan Bupati Purwakarta.
Dalam proses perencanaan, SMP Negeri 1 Purwakarta menyelenggarakan rapat awal tahun pelajaran. Dalam rapat tersebut dilaksanakan pengkajian visi dan misi sekolah yang akan digunakan dalam tahun ajaran baru. Pengkajian visi misi sekolah dilaksanakan dengan mempertimbangkan hasil evaluasi dan pengkajian masalah yang terjadi di tahun ajaran sebelumnya. Selain itu, pengkajian tersebut mengacu pada berbagai kebutuhan fisik maupun non fisik yang belum terpenuhi. Setelah adanya pengkajian tersebut, visi misi sekolah disesuaikan dengan tujuan dari Program Pendidikan Berkarakter. Pada akhirnya terbentuklah tujuan, visi, dan misi sekolah yang terintegrasi dengan Program Kabupaten Purwakarta.

Pengembangan nilai-nilai dalam pendidikan karakter di Indonesia menurut Zubaedi (2011, hlm. 73) diidentifikasi berasal dari empat sumber, yaitu agama, Pancasila, budaya, dan tujuan pendidikan nasional. Kajian visi misi SMP Negeri 1 Purwakarta menyandarkan pengembangannya pada nilainilai keagamaan dan kepercayaan kepada Tuhan Yang Maha Esa, sehingga realisasinya terdapat banyak perencanaan yang berkaitan dengan kegiatan religius.

Selanjutnya visi misi yang telah ditetapkan kemudian dijabarkan dalam bentuk program. Tahap dalam perencanaan ini disebut sebagai tahap penentuan program. Menurut 
Suharto (2014, hlm. 78-79) terdapat beberapa tahapan dalam menyusun program diantaranya yaitu (1) identifikasi program alternatif; (2) penentuan hasil program; (3) penentuan biaya; dan (4) kriteria pemilihan program. Tahap penentuan program yang dilaksanakan para pemangku kebijakan di SMP Negeri 1 Purwakarta menghasilkan beberapa program yang meliputi program mingguan, bulanan, dan tahunan.

Tahap terakhir dalam perencanaan yaitu penentuan komponen penunjang program. Komponen penunjang program ini berkaitan dengan kebutuhan yang harus disediakan serta kepanitiaan program. Kebutuhan program ditentukan dari hasil analisis kebutuhan atau need assessment. Hasim dan Remiswal (2009, hlm. 123) yang menyatakan bahwa need assessment dilakukan untuk menentukan skala prioritas, yaitu kebutuhan mana yang mesti diprioritaskan dan kebutuhan mana sebagai penunjang saja. Dengan mengetahui prioritas, maka tersusunlah program satu tahun ajaran yang sudah memuat sasaran dan tujuan, waktu kegiatan, biaya, serta kepanitiaan.

Need assessment memudahkan sekolah dalam menentukan berbagai kebutuhan yang harus diwujudkan dan diprioritaskan menjadi program utama atau program tambahan. Selanjutnya adalah penentuan tim pelaksana atau ketua dan penanggung jawab kegiatan yang akan dilaksanakan. Penentian sumber daya manusia ini sangat penting dilakukan dalam sebuah manajerial sekolah. Progam akan terlaksana jika pembagian tugas merata dan tidak memberatkan beberapa pihak saja.

\section{Pelaksanaan}

Pendidikan berkarakter dilaksanakan dengan tiga basis proses penanaman. Tiga basis tersebut yaitu dalam pembelajaran di kelas atau dalam program kurikuler, dalam ekstrakurikuler, dan dalam kebiasaan di sekolah maupun di luar sekolah. Implementasi ini didukung oleh pendapat Koeosoema (dalam Muslich, 2015, hlm. 90-91) yang menyatakan bahwa pendidikan berkarakter sebagai implementasi pengembangan pendidikan karakter di jenjang pendidikan dasar dan menengah meliputi tiga basis utama, yaitu: (1) desain pendidikan karakter berbasis kelas; (2) desain pendidikan karakter berbasis kultur sekolah; dan (3) desain pendidikan karakter berbasis komunitas.

Berdasarkan hasil data lapangan, Program Pendidikan Berkarakter yang diimplementasikan dalam pembelajaran di kelas, dalam ekstrakurikuler, dan pembiasaan sekolah maupun di luar sekolah. Adapun pembahasan implementasinya adalah sebagai berikut:

\section{Implementasi dalam Pembelajaran di Kelas}

Pelaksanaan pendidikan karakter di SMP Negeri 1 Purwakarta diselenggarakan dalam seluruh mata pelajaran di kelas sebagai bentuk upaya guru dalam melaksanakan tanggung jawab profesinya. Upaya tersebut merupakan bagian dari penyelenggaraan pendidikan karakter. Zubaedi (2011, hlm. 19) menyatakan bahwa pendidikan karakter adalah segala upaya yang dilakukan oleh guru untuk mempengaruhi peserta didik. Salah satu mata pelajaran yang menyelenggarakan Pendidikan Karakter adalah Mata Pelajaran Pendidikan Kewarganegaraan (PKn).

PKn mengambil peran strategis dalam mengimplementasikan program pendidikan berkarakter. John Mahoney yang dikutip Suriakusumah (dalam Wuryan dan Syaifullah, 2013, hlm 75) menyatakan bahwa Pendidikan Kewarganegaraan adalah "Civic Education includes and involves those teachings that type of teaching method, those student activities, those administratives and supervisory procedure which the school may utilize purposively to make for better living together in the democratic way or (synonymously) to develop better civic behavior. Pendidikan Kewarganegaraan mencakup berbagai kegiatan sekolah seperti metode mengajar, kegiatan siswa, masalah administrasi, dan prosedur pengawasan yang sesuai dengan tujuan sekolah yaitu membina kehidupan bersama yang lebih baik dengan cara demokratis atau sinonim dengan mengembangkan perilaku warga negara yang baik. Implementasi pendidikan berkarakter dilaksanakan bukan hanya dalam pembelajaran saja.

Beberapa proses implementasi berdasarkan hasil pengamatan lapangan, pelaksanaan pendidikan berkarakter dalam kelas meliputi: (1) pelaksanaan berliterasi untuk membuka wawasan dengan membaca buku sebelum pembelajaran dimulai; (2) mengucap ikrar berpancasila sebelum pembelajaran dimulai; dan (3) mendengarkan atau menyanyikan langsung lagu-lagu sesuai dengan tema hari yang ditentukan dalam program Tujuh Poe Atikan Purwakarta, misalnya lagu nasional dan lagu daerah. 
Ketiga aktivitas pembelajaran tersebut memungkinkan internalisasi dan pengalaman nilai-nilai karakter terlaksana dalam aktivitas sehari-hari. Mereka diajak untuk menginternalisasikan substansi ideologis bangsa Indonesia dengan mengucap ikrar berpancasila. Selain itu, kompetensi kognitif tentang nilai dibangun melalui literasi. Adapun implementasi Tujuh Poe Atikan Purwakarta membuat peserta didik mendapatkan pembelajaran terkait tata nilai budaya Purwakarta yang setiap harinya. Adapun pelembagaan karakter toleransi dalam kegiatan kurikuler di SMPN 1 Purwakarta yakni

pertama Pembelajaran selalu mendorong siswa untuk bekerja sama dengan siapa saja meskipun berbeda agama. Kedua Pembiasaan ikrar berpancasila mengupayakan untuk menghayati nilai-nilai religius serta menghormati setiap perbedaan untuk persatuan. Ketiga Menyanyikan lagu-lagu daerah memberikan suasana persatuan di kelas serta mengajak siswa untuk memiliki satu rasa cinta bangsa dan budaya meskipun dengan latar belakang yang berbeda

Inti dari implementasi pendidikan berkarakter di dalam pembelajaran adalah bahwa pendidikan berkarakter sebagai program pendidikan dilaksanakan dalam proses pembelajaran yang berbasis relasi guru sebagai pendidik dan siswa sebagai pembelajar. Dalam pembelajaran ini terjadi proses penanaman nilai yang secara langsung berpengaruh terhadap perilaku siswa. Guru memberikan pengalaman belajar dalam bentuk kognitif, afektif maupun psikomotorik.

Kaitan dengan penanaman nilai-nilai toleransi, proses pembelajaran memberikan pembiasaan kepada siswa untuk saling menghargai dan menghormati setiap perbedaan pandangan atau pendapat dikelas. Mereka dibiasakan untuk berkolaborasi membangun kebersamaan untuk menyelesaikan masalah. Proses yang terjadi dalam lingkungan kelas di SMP Negeri 1 Purwakarta menjelaskan bahwa pendidikan toleransi terjadi saat pembelajaran di kelas.

\section{Implementasi dalam Ekstrakurikuler}

Implementasi Program Pendidikan Berakarakter meliputi program ekstrakurikuler. Dalam Peraturan Bupati Nomor 69 Tahun 2015 pasal 3 menyatakan bahwa Prinsip penyelenggaraan pendidikan berkarakter di Kabupaten Purwakarta dilaksanakan secara terintegrasi melalui kegiatan ekstra kurikuler. Pasal tersebut merupakan bentuk penugasan bahwa Program Pendidikan Berkarakter diimplementasikan dalam ekstrakurikuler.

Pelaksanaan pendidikan berkarakter dalam ekstrakurikuler adalah upaya pengintegrasian nilai-nilai karakter dalam aktivitas kesiswaan yang meliputi pengembangan minat dan bakat siswa. Ekstrakurikuler adalah wadah dalam mempraktikan setiap pengetahuan tentang nilai karakter dalam berbagai aktivitas bermakna. Pendidikan Karakter yang diimplementasikan dalam ekstrakurikuler tentu memiliki berbagai perbedaan fokus nilai. Misalnya Pramuka menurut Budimansyah (2010, hlm. 90) menjadi sarana dalam memperoleh sejumlah karakter dalam konteks kehidupan demokratis dan sadar hukum. Selain itu dalam pramuka siswa dilatih untuk bekerja sama dan menjalin persatuan dengan berbagai aktivitas seperti mempelajari sejarah kepanduan, perkemahan, perlombaan, hiking, latihan kepemimpinan dan lain sebagainya.

Berkaitan dengan penanaman nilai toleransi, dalam pelaksanaan ekstrakurikuler hal yang menarik adalah adanya penerapan nilainilai religius. Setiap waktu Ashar, aktivitas ekstrakurikuler dihentikan sementara untuk menunaikan shalat berjamaah dengan imamnya bergiliran dari setiap ekstrakurikuler yang sedang berkegiatan. Implementasi Pendidikan Berkarakter juga dicerminkan dalam pelaksanaan kegiatan pendalaman kitab kuning yang dilaksanakan untuk memberikan pengetahuan tentang berbagai kitab kuning yang dipelajari di pesantren-pesantren. Kitab kuning ini dilakukan untuk memberikan pengetahuan tentang berbagai pelajaran tentang kitab-kitab kuning yang dipakai di berbagai pesantren di Indonesia.

\section{Implementasi dalam Pembiasaan Sekolah dan Luar Sekolah}

Pendidikan berkarakter diterapkan melalui berbagai aktivitas seperti: Pertama Penguatan sikap toleransi dilaksanakan dalam pembiasaan hari jumat (Nyucikeun Diri) dengan pembiasaan beribadah bersama dalam waktu yang sama namun di tempat peribadatan yang berbeda-beda. Kedua Toleransi ditumbuhkan dalam pembiasaan makan bekel dimana setiap orang saling berbagi makanan meskipun berbeda agama dan latar belakang. Ketiga sikap toleransi ditumbuhkan dalam kegiatan bulanan yang diselenggarakan pemerintah Kabupaten dengan 
mengajak siswa untuk makan bersama saling suap menyuap antara siswa yang berbeda agama.

Ketiga kegiatan di atas merupakan bentuk pembiasaan yang dilakukan di sekolah sebagai bagian dari upaya pelembagaan karakter toleransi siswa khususnya dalam perbedaan agama. Adapun pembiasaan menurut Mulyasana (2011, hlm. 166) adalah sebagai sesuatu yang sengaja dilakukan secara berulang-ulang agar sesuatu itu dapat menjadi kebiasaan.

Dalam psikologi terdapat konsep operan conditioning yang menurut Skinner (1938) menyatakan bahwa "Operant conditioning can be described as a process that attempts to modify behavior through the use of positive and negative reinforcement. Through operant conditioning, an individual makes an association between a particular behavior and a consequence". Artinya bahwa Operant Conditioning dapat digambarkan sebagai proses yang mencoba untuk mengubah perilaku melalui penggunaan penguatan positif dan negatif. Melalui pengkondisian operan, seseorang membuat hubungan antara perilaku tertentu dan konsekuensinya

Maka dalam hal ini, kegiatan-kegiatan yang telah dijelaskan di atas termasuk ke dalam pembiasaan sekolah atau budaya sekolah yang merupakan salah satu sarana penting dalam proses penanaman nilai-nilai karakter siswa dan warga sekolah lainnya sebagai bagian dari proses operant conditioning. Pembiasaan sekolah adalah perilaku yang menjadi aturan tertulis maupun tidak tertulis yang dilaksanakan secara berulang terus menerus. Kegiatan berulang ini diharapkan mampu melembaga dalam kehidupan peserta didik. Bentuk-bentuk pembiasaan di sekolah menurut Zubaedi (2011, hlm. 19) yaitu dilakukan melalui: (1) penugasan; (2) pembiasaan; (3) pelatihan; (4) pengajaran; (5) pengarahan; dan (6) keteladanan. Ke enam hal ini menjadi salah satu upaya untuk mewujudkan pendidikan karakter yang berbasis pada kebiasaan sekolah.

Itulah beberapa proses pelembagaan nilainilai toleransi dalam penerapan pendidikan berkarakter dalam pembiasaan di sekolah maupun di luar sekolah. Berdasarkan hasil wawancara, pembiasaan ini memberikan dampak yang besar dalam memberikan penguatan terhadap perilaku siswa untuk tidak melakukan hal-hal yang menyimpang dari aturan sekolah khususnya yang berkaitan dengan masalah intoleransi.

\section{Monitoring dan Evaluasi}

Monitoring adalah pengawasan jalannya program untuk mengetahui masalah yang terjadi dalam pelaksanaan, mengontrol setiap pihak yang terlibat dalam program dan mengetahui perkembangan dari program tersebut. Evaluasi kegiatan sendiri menurut Suharto (2014, hlm. 119) pengidentifikasian keberhasilan dan/atau kegagalan suatu rencana kegiatan atau program. Artinya, evaluasi merupakan cara untuk mengetahui apakah implementasi pendidikan berkarakter adalah sebuah kegagalan atau keberhasilan. Frutchey (dalam Mardikanto dan Soebiato, 2015, hlm. 265), kegiatan evaluasi selalu mencakup kegiatan: (1) observasi; (2) membanding-bandingkan antara hasil pengamatan dengan pedoman yang ada atau telah ditetapkan lebih dahulu; dan (3) pengambilan keputusan atau penilaian atas objek yang diamati.

Berdasarkan hasil dokumentasi lapangan, Peraturan Bupati Purwakarta Nomor 69 Tahun 2015 pasal 31 ayat (1) menyatakan bahwa Pengawasan atas pelaksanaan kebijakan Pendidikan Berkarakter sebagaimana diatur dalam Peraturan Bupati pada tingkat kabupaten dilaksanakan oleh Kepala Disdikpora, dan pada tingkat satuan pendidikan dilaksanakan oleh Pengawas Satuan Pendidikan. Artinya pelaksana monitoring adalah Dinas Pendidikan Pemuda dan Olahraga dan pengawas satuan pendidikan. Setelah melakukan pengawasan, Disdikpora harus memberikan evaluasi kepada setiap sekolah termasuk SMP Negeri 1 Purwakarta yang selanjutnya disampaikan secara langsung berupa saran dan masukan bagi bupati sebagai lembaga eksekutif daerah yang melaksanakan kebijakan.

Dalam hasil lapangan, evaluasi yang dilakukan adalah dengan mekanisme monitoring setiap kegiatan yang berjalan dalam waktu yang berkala. Sekolah membuat evaluasi dalam dua cara, yaitu dilakukan setelah kegiatan selesai, khususnya yang berkaitan dengan kegiatan besar diluar pembiasaan. Cara lainnya adalah evaluasi dilakukan setelah program berjalan selama satu semester. Hasil dari laporan tersebut kemudian diserahkan kepada pihak Dinas Pendidikan Pemuda dan Olahraga. Setelah satu tahun pelajaran selesai, Disdikpora menyampaikan laporan kepada pemerintah kabupaten khususnya Bupati Purwakarta.

Melihat mekanisme monitoring dan evaluasinya, dapat diketahui bahwa tipe dari evaluasi yang dilaksanakan dalam program 
pendidikan berkarakter mengikuti pendapat dari Suharto (2014, hlm. 119) yaitu on going evaluation atau evaluasi terus menerus, dan tipe ex-post evaluation atau evaluasi akhir.

On going evaluation dilakukan pemerintah khususnya Disdikpora dengan memantau secara terus menerus dan memberikan masukan serta saran saat program sedang berjalan. Kegiatan evaluasi tipe ini terus dilaksanakan dengan jangka waktu yang berkala melalui monitoring. Sedangkan tipe ex-post evaluation, pelaksanaan evaluasi program Pendidikan Berkarakter dilaksanakan setelah program selesai misal dalam satu tahun.

SMP Negeri 1 Purwakarta berperan dalam (1) pelaksana setiap teknis yang tercantum dalam Peraturan Bupati Nomor 69 Tahun 2015; (2) penyedia sarana prasarana untuk menunjang setiap program yang dilaksanakan sebagai turunan dari kebijakan Pendidikan Berkarakter; (3) mengupayakan terciptanya lingkungan pendidikan yang bebas dalam beribadah dan tidak ada pembatasan apapun; (4) pihak yang mengupayakan terbangunnya toleransi dalam beberapa basis pendidikan, baik dalam pembelajaran di kelas, kegiatan kesiswaan atau ekstrakurikuler maupun kegiatan pembiasaan yang dilaksanakan setiap hari; dan (5) sebagai tempat untuk melatih karakter peserta didik guna meningkatkan kualitas mutu lulusan. Adapun dua komponen sekolah yang berperan strategis dalam implementasi Pendidikan Berkarakter di SMP Negeri 1 Purwakarta yaitu Kepala Sekolah dan Guru setiap mata pelajaran

\section{SIMPULAN DAN SARAN}

\section{Simpulan}

Implementasi pendidikan berkarakter diawali dengan perencanaan yang meliputi: (1) pengkajian visi misi sekolah; (2) penentuan program yang dilaksanakan; dan (3) penentuan komponen penunjang program. Selanjutnya diimplementasikan dalam tiga basis yaitu: (1) Pembelajaran di kelas/kurikuler; ekstrakurikuler dan (3) Pembiasaan di kelas maupun di luar kelas. Adapun implementasi pada tahap evaluasi dilaksanakan dengan dua tipe yaitu on going evaluation atau evaluasi secara terus menerus saat program berjalan; dan ex-post evaluation yaitu evaluasi yang dilaksanakan secara menyeluruh setelah program kegiatan selesai dilaksanakan.

Saran
Dari hasil pembahasan dan kesimpulan maka penulis dapat memberikan saran agar sekolah dapat mengoptimalkan peranya sebagai pelaksana teknis, penyedia sarana prasarana, penjamin pelaksanaan, sebagai pihak yang bertanggungjawab menciptakan kondisi sekolah toleran, sebagai wadah dalam melatih dan membina siswa dalam upaya melembagakan karakter toleransi beragama.

\section{DAFTAR PUSTAKA}

Budimansyah, (2010) Penguatan Pendidikan Kewarganegaraan Untuk membangun Karakter Bangsa. Widya Aksara Press.

Creswell, J.W. (1998). Qualitative Inquiry and Research Design, Choosing. Among Five Traditions. London: Sage Publication.

Hasim, dan Remiswal. (2009). Community Development Berbasis Ekosistem. Jakarta: Diadit Media.

Mardikanto, T. dan P. Soebiato. (2015). Pemberdayaan Masyarakat dalam Perspektif Kebijakan Publik. Bandung: Alfabeta.

Muslich, (2011) Pendidikan Karakter. Jakarta: PT Bumi Aksara.

Mulyasana, D. (2011). Pendidikan Bermutu dan Berdaya Saing. Bandung: Remaja Rosdakarya.

Peraturan Bupati No 69 Tahun 2015 Tentan Pendidikan Berkarakter Purwakarta.

Poerwadarminta W.J.S. (1982). Kamus Umum Bahasa Indonesia. Jakarta: Balai Pustaka.

Purwasasmita, M. (2010). Memaknai Konsep Alam Cerdas dan Kearifan Nilai Budaya Lokal (Cekungan Bandung, Tatar Sunda, Nusantara, dan Dunia) Peran Local Genius dalam Pendidikan Karakter Bangsa. Prosiding Seminar. Bandung: Widya Aksara Press.

Skinner, B.F. (1938). The Behavior of Organisms: An Experimental Analysis. Cambridge Massachusetts: B. F. Skinner Foundation.

Suharto, E. (2014). Membangun Masyarakat Memberdayakan Rakyat: Kajian Strategis 
Citizenship Jurnal Pancasila dan Kewarganegaraan Vol 6 No 1 April 2o18, hal 17-29

Avaliable online at : http://e-journal.unipma.ac.id/index.php/Citizenship

Print ISSN: 2302-433X Online ISSN : 2579-5740

Kesejahteraan Sosial dan Pekerjaan

Sosial. Bandung: Refika Aditama.

Undang-Undang Republik Indonesia Nomor

20 Tahun 2003 Tentang Sistem

Pendidikan Nasional

Wuryan, S. dan Syaifullah. (2006). Ilmu

Kewarganegaraan (Civics). Bandung:

Laboratorium Pendidikan

Kewarganegaraan.

Zubaedi, (2011). Desain Pendidikan

Karakter. Jakarta: Prenada Media

Group 